\title{
Effects of arsenic and its interaction with phosphorus on yield and arsenic accumulation in rice
}

\author{
M. Begum, J. Akter, M. Jahiruddin and M.R. Islam \\ Department of Soil Science, Bangladesh Agricultural University, Mymensingh-2202, Bangladesh
}

\begin{abstract}
A study was made on the effect of arsenic (As) and As X $P$ interaction in Boro rice and its residual effect in succeeding T. Aman rice. Arsenic was added to soil (having $2.6 \mathrm{ppm}$ initial As) @ 0,15 and $30 \mathrm{mg}$ As $\mathrm{kg}^{-1}$ from $\mathrm{Na}_{2} \mathrm{HAsO}_{4} .7 \mathrm{H}_{2} \mathrm{O}$ and phosphorus @ 0, 20, 40, 60 and $80 \mathrm{mg} \mathrm{P} \mathrm{kg}^{-1}$ from $\mathrm{KH}_{2} \mathrm{PO}_{4}$. Each pot had received 100 ppm N, 40 ppm K and 25 ppm S from urea, MoP and gypsum, respectively. The grain yield of Boro rice was reduced by $20.6 \%$ for 15 ppm As treatment and $63.8 \%$ due to 30 ppm As. Such reductions for straw yield were 21.0 and $65.2 \%$ with these two As treatments, respectively. Residual effect of arsenic was also significant and negative in T. Aman rice. The grain-As concentration in all cases was below $1 \mathrm{ppm}$, and the straw-As content was well above 1 ppm. The arsenic concentrations of both grain and straw were lower in T. Aman rice than in Boro rice. The adverse effect of arsenic was further enhanced by $\mathrm{P}$ addition. This reaction has an implication to $\mathrm{P}$ fertilizer management in rice.
\end{abstract}

Keywords: Arsenic, Rhosphorus, Rice

\section{Introduction}

Arsenic (As) contamination of groundwater is a severe problem in Bangladesh and this has affected at least 25 million people (Ravenscroft et al., 2005). Next to drinking water, rice could be a potential source of As exposure of the people living in the As affected areas of Bangladesh (Hossain et al., 2008). Roberts et al. (2007) estimated that over 1000 tons of As might be transferred to arable land each year from As contaminated groundwater irrigation, creating a potential risk for future food (rice) production.

Arsenic may enter into human body directly through drinking water and indirectly through foods, chiefly rice for Bangladeshi people. Rice covers about $75 \%$ of the total cropped areas in this country. Many areas have high groundwater and soil arsenic contents which is likely to be taken up by plants through roots and transported to the aerial parts (Jahiruddin et al., 2000; Huq et al., 2006; Williams et al., 2006). Islam et al. (2005) reported 12.3 ppm mean As over 456 soil samples across the country. Phosphorus fertilization is common in rice cultivation which might interact with arsenic uptake since phosphate is an analogue of arsenate (Beever and Burns, 1980) and compete for the same sorption sites (Qafoku et al., 1999). Considering the above point in view, the present study was made to evaluate the effect of arsenic and its interaction with $P$ on yield loss and arsenic accumulation in rice. The experiment was conducted with varying doses of arsenic addition to soil having low arsenic content in order to understand the situation in high arsenic soil. The effect of added arsenic was monitored first on Boro rice and then its residual effect on the following $\mathrm{T}$. Aman rice.

\section{Materials and Methods}

A pot-culture experiment was set up during Boro season of 2004 with BAU farm soil having low arsenic content $(2.6 \mathrm{ppm})$ in a net-house of the Department of Soil Science of Bangladesh Agricultural University (BAU), Mymensingh. Texturally the soil was silt loam with $6.7 \mathrm{pH}, 2.28 \%$ organic carbon, $0.28 \%$ total $\mathrm{N}, 9.8 \mathrm{ppm}$ available $\mathrm{P}, 14 \mathrm{ppm}$ available $\mathrm{S}, 0.7$ ppm available $\mathrm{Zn}$ and $0.11 \mathrm{c} \mathrm{mol} \mathrm{kg}^{-1}$ exchangeable $\mathrm{K}$. The size of each pot was $43 \mathrm{~cm}$ in diameter and $40 \mathrm{~cm}$ in height. There were 15 treatments consisting of three doses of As $(0,15$ and $30 \mathrm{ppm})$ and five doses of $P(0,20,40,60$ and $80 \mathrm{ppm})$, their sources being 
$\mathrm{Na}_{2} \mathrm{HAsO}_{4} .7 \mathrm{H}_{2} \mathrm{O}$ and $\mathrm{KH}_{2} \mathrm{PO}_{4}$, respectively. It's a two factor experiment arranged in a completely randomized design with three replications. The seedlings (cv. BRRI dhan29) were transplanted in the pots on 26 January 2004. After harvest, the T. Aman rice (cv. BRRI dhan33) was transplanted in the same pots on 31 July 2004 to see the residual effect of previously added arsenic. For both crops, every pot had received $100 \mathrm{ppm} \mathrm{N}$ from urea, 40 ppm $\mathrm{K}$ from MoP and $25 \mathrm{ppm} \mathrm{S}$ from gypsum. Nitrogen was added in three splits, the first split during final land preparation and the remaining splits at 35 days and 60 days after transplanting. Intercultural operations such as weeding and irrigation were done whenever required. The crops were harvested at maturity and the data on yield and yield parameters were recorded. Plants of all three hills from each pot were measured and averaged to record the yield contributing characters. The grain and straw samples were analyzed for N, P and As contents. All the plants data were statistically analyzed following F-test and the difference between treatment means was adjudged by Duncan's Multiple Range Test (DMRT).

\section{Results and Discussion}

The effects of arsenic and its interaction with phosphorus on the yield, yield components, arsenic accumulation, and $\mathrm{N}$ and $\mathrm{P}$ concentrations in rice (Boro and $\mathrm{T}$. Aman rice) are described below under various sub-heads. The data are shown in Tables 1-4.

\section{Effects of As and As X P interaction on Boro rice}

\section{Effect on yield}

Both grain and straw yields were significantly reduced due to arsenic toxicity. The grain yields due to three arsenic treatments $(0,15$ and $30 \mathrm{ppm} \mathrm{As})$ were $74.17,58.86$ and $26.84 \mathrm{~g} \mathrm{pot}^{-1}$ and the corresponding straw yields were $86.00,67.94$ and $29.94 \mathrm{~g} \mathrm{pot}^{-1}$, all were significantly different from each other (Table 1). Compared to the control pot, the yield reductions were 20.6 and $63.8 \%$ in grain, and 21.0 and $65.2 \%$ in straw, for the $\mathrm{As}_{15}$ and $\mathrm{As}_{30}$ treatments, respectively. It appeared that the toxic effect of added arsenic on grain and straw yields were deteriorated due to added $\mathrm{P}$ showing a negative interaction (Fig. 1). For example, the grain yields due to $A s_{30}$ treatment with different doses of $P$ viz. $P_{0}, P_{20}, P_{40}, P_{60}, \& P_{80}$ were 35.55 , 23.22, 19.96, 29.20 and $26.28 \mathrm{~g}$ per pot, respectively. The highest yield in both cases was observed with $\mathrm{P}_{80} \mathrm{As} \mathrm{s}_{0}$ treatment and the lowest yields with $\mathrm{P}_{80} \mathrm{As}_{30}$.

Table 1. Effects of arsenic and phosphorus on the yield and yield components of Boro rice (cv. BRRI dhan29)

\begin{tabular}{|c|c|c|c|c|c|}
\hline $\begin{array}{l}\text { Treatment } \\
\text { (As or } \mathrm{P})\end{array}$ & $\begin{array}{l}\text { Effective tillers } \\
\text { pot }^{-1}\end{array}$ & $\begin{array}{l}\text { Filled grains } \\
\text { panicle }\end{array}$ & $\begin{array}{l}\text { 1000-grain } \\
\text { weight }(\mathrm{g})\end{array}$ & $\begin{array}{c}\text { Grain yield } \\
\left(\mathrm{g} \mathrm{pot}^{-1}\right)\end{array}$ & $\begin{array}{c}\text { Straw yield } \\
\left(\mathrm{g} \mathrm{pot}^{-1}\right)\end{array}$ \\
\hline \multicolumn{6}{|l|}{ As (ppm) } \\
\hline 0 & $33.60^{a}$ & $96.72^{\mathrm{a}}$ & $24.53^{a}$ & $74.17^{a}$ & $86.00^{\mathrm{a}}$ \\
\hline 15 & $31.33^{b}$ & $92.14^{a}$ & $24.94^{a}$ & $58.86^{b}$ & $67.94^{b}$ \\
\hline 30 & $23.40^{C}$ & $49.57^{b}$ & $21.11^{b}$ & $23.81^{\mathrm{C}}$ & $29.94^{\mathrm{C}}$ \\
\hline S.E. ( \pm$)$ & 0.89 & 4.55 & 0.42 & 2.98 & 1.98 \\
\hline \multicolumn{6}{|l|}{$\mathrm{P}(\mathrm{ppm})$} \\
\hline 0 & 29.67 & 82.15 & 22.58 & 58.95 & 64.91 \\
\hline 20 & 29.44 & 77.38 & 22.75 & 54.09 & 66.62 \\
\hline 40 & 32.00 & 71.97 & 23.52 & 48.37 & 57.51 \\
\hline 60 & 27.89 & 79.43 & 24.49 & 50.92 & 58.51 \\
\hline 80 & 28.22 & 86.41 & 24.28 & 49.06 & 58.92 \\
\hline S.E. $( \pm)$ & NS & NS & NS & NS & NS \\
\hline
\end{tabular}

S.E. $=$ Standard error of means $\quad$ NS $=$ Treatment effect not significant

In a column, the figures having same letter do not differ significantly at $5 \%$ level by DMRT. 

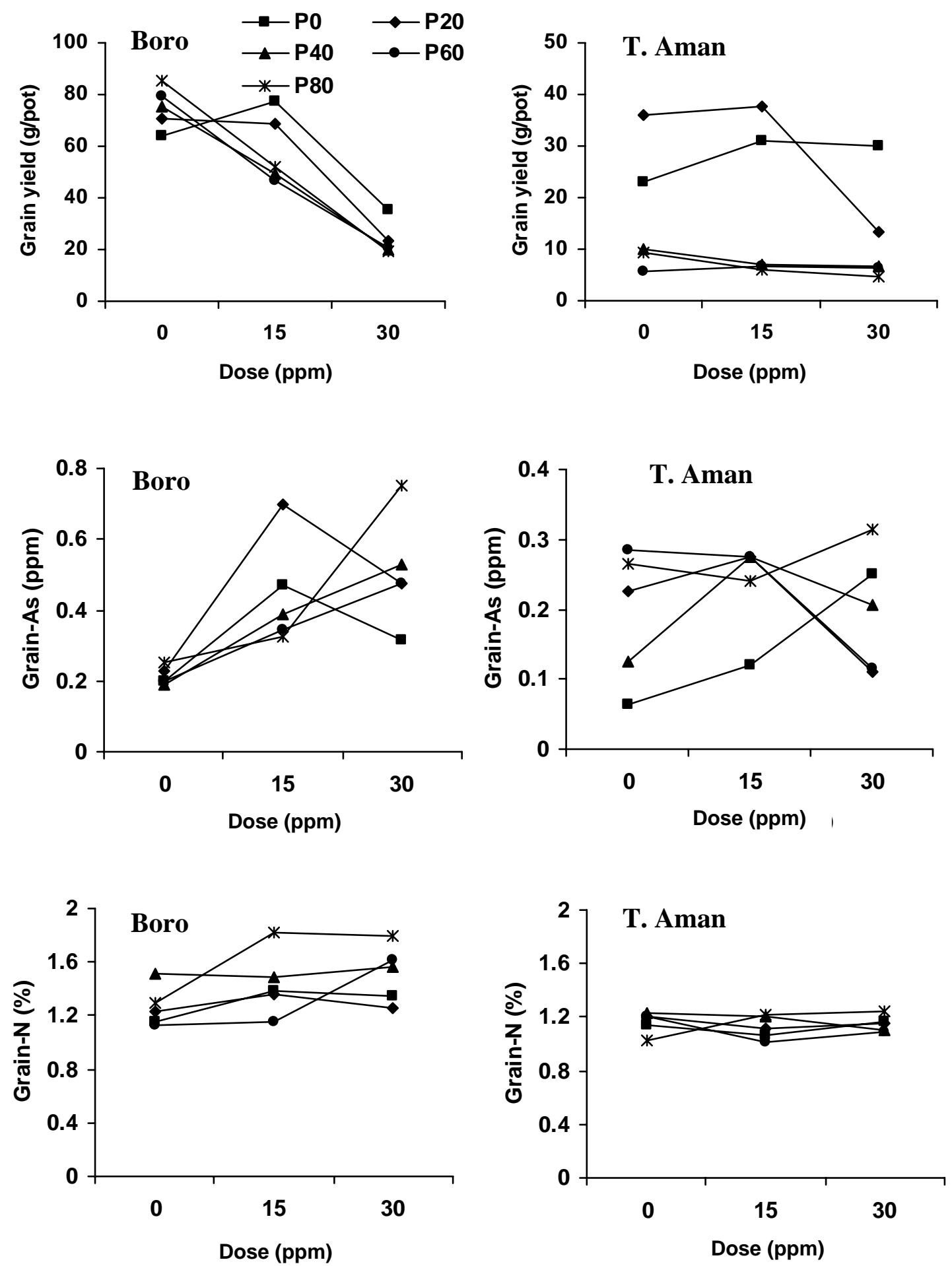

Fig. 1. Interaction effect of arsenic and phosphorus on the yield, arsenic and nitrogen concentrations of rice (Legend same for all graphs) 


\section{Effect on yield parameters}

Addition of arsenic at $30 \mathrm{ppm}$ rate produced a highly significant toxic effect on the effective tillers pot ${ }^{-1}$, filled grains panicle ${ }^{-1}$ and 1000 -grain weight (Table 1). However, the toxic effect due to $15 \mathrm{ppm}$ arsenic treatment was not significant. The number of effective tillers pot ${ }^{-1}$ for 0,15 and $30 \mathrm{ppm}$ arsenic treatments were $33.60,31.33$ and 23.40 , respectively. The corresponding values for the number of filled grains panicle ${ }^{-1}$ were $96.72,92.14$ and 49.57 . The 1000-grain weights for the arsenic treatments followed the order of 24.53, 24.94 and $21.11 \mathrm{~g}$. There was no significant interaction of As and P on these three characters.

\section{Effect on As, $\mathbf{N}$ and $P$ concentrations}

Arsenic concentrations of both grain and straw had increased as the dose of arsenic increased, the range being $0.214-0.507 \mathrm{ppm}$ As for grain and $2.55-8.27 \mathrm{ppm}$ As for straw (Table 2). The treatment with $15 \mathrm{ppm}$ As had a grain-As concentration of $0.376 \mathrm{ppm}$ and straw-As of $6.01 \mathrm{ppm}$. The As content also varied with the $P$ doses with a result of $0.339-$ $0.442 \%$ in grain and $4.84-7.47 \%$ in straw. The As X P interaction was significant showing the maximum As concentration $\left(0.75 \mathrm{ppm}\right.$ in grain and $10.17 \mathrm{ppm}$ in straw) for $\mathrm{P}_{80} \mathrm{As}_{30}$ treatment in both grain and straw (Fig. 1, straw data not shown).

Table 2. Effects of arsenic and phosphorus on the $A s, N$ and $P$ concentrations in Boro rice (cv. BRRI dhan29)

\begin{tabular}{|c|c|c|c|c|c|c|}
\hline \multirow{2}{*}{$\begin{array}{l}\text { Treatment } \\
\text { (As or } \mathrm{P} \text { ) }\end{array}$} & \multicolumn{2}{|c|}{$\mathrm{N}$ conc. $(\%)$} & \multicolumn{2}{|c|}{$\mathrm{P}$ conc. (\%) } & \multicolumn{2}{|c|}{ As conc. (ppm) } \\
\hline & Grain & Straw & Grain & Straw & Grain & Straw \\
\hline \multicolumn{7}{|l|}{ As (ppm) } \\
\hline 0 & $1.264^{\mathrm{C}}$ & $0.572^{b}$ & $0.301^{c}$ & $0.107^{\mathrm{a}}$ & $0.214^{\mathrm{C}}$ & $2.55^{\mathrm{c}}$ \\
\hline 15 & $1.441^{b}$ & $0.800^{a}$ & $0.345^{b}$ & $0.076^{b}$ & $0.376^{b}$ & $6.01^{b}$ \\
\hline 30 & $1.520^{\mathrm{a}}$ & $0.839^{a}$ & $0.410^{\mathrm{a}}$ & $0.085^{b}$ & $0.507^{\mathrm{a}}$ & $8.27^{\mathrm{a}}$ \\
\hline S.E. $( \pm)$ & 0.012 & 0.027 & 0.009 & 0.005 & 0.012 & 0.20 \\
\hline \multicolumn{7}{|l|}{$\mathrm{P}(\mathrm{ppm})$} \\
\hline 0 & $1.291^{\mathrm{C}}$ & $0.796^{\mathrm{a}}$ & $0.291^{\mathrm{C}}$ & $0.065^{c}$ & $0.43^{\mathrm{ab}}$ & $5.03^{b}$ \\
\hline 20 & $1.284^{\mathrm{C}}$ & $0.588^{b}$ & $0.353^{b}$ & $0.071^{c}$ & $0.35^{c}$ & $5.27^{b}$ \\
\hline 40 & $1.524^{b}$ & $0.773^{\mathrm{a}}$ & $0.339^{\mathrm{bc}}$ & $0.094^{b}$ & $0.44^{\mathrm{a}}$ & $4.84^{b}$ \\
\hline 60 & $1.298^{\mathrm{C}}$ & $0.844^{\mathrm{a}}$ & $0.367^{\mathrm{ab}}$ & $0.118^{\mathrm{a}}$ & $0.34^{c}$ & $5.46^{b}$ \\
\hline 80 & $1.644^{\mathrm{a}}$ & $0.684^{\mathrm{ab}}$ & $0.410^{\mathrm{a}}$ & $0.099^{b}$ & $0.37^{\mathrm{abc}}$ & $7.47^{\mathrm{a}}$ \\
\hline S.E. $( \pm)$ & 0.016 & 0.035 & 0.011 & 0.006 & 0.016 & 0.26 \\
\hline
\end{tabular}

S.E. = Standard error of means

In a column, the figures having same letter do not differ significantly at $5 \%$ level by DMRT.

Similar to arsenic, the $\mathrm{N}$ content in grain and straw increased with increasing addition of arsenic. The grain- $\mathrm{N}$ varied from $1.264-1.520 \%$ and the straw- $\mathrm{N}$ from $0.572-0.839 \%$ (Table 2). There was a significant As $\times \mathrm{P}$ interaction for grain- $\mathrm{N}$ content while the straw $\mathrm{N}$ content remained unaffected. The highest $\mathrm{N}$ concentration in grain $(1.82 \%)$ was noted in $\mathrm{P}_{80} \mathrm{As}_{15}$ treatment (Fig. 1).

The $P$ content of rice grain also increased with arsenic doses but the reverse was true for straw-P content (Table 2$)$. Thus, the highest grain-P concentration $(0.41 \%)$ was recorded by the $30 \mathrm{ppm}$ As treatment while for the straw-P (0.107\%) the highest record was obtained with the As control. The As- $P$ interaction was found significant with the maximum grain- $P$ concentration $(0.437 \%)$ in $\mathrm{P}_{80} \mathrm{As}_{30}$ and the maximum straw-P content $(0.151 \%)$ in $\mathrm{P}_{20} \mathrm{As}_{0}$ treatments (Fig. 1, straw data not shown). 


\section{Residual effect of As and As $x \mathrm{P}$ interaction on $\mathrm{T}$. Aman rice}

\section{Effect on yield}

There was a remarkable residual effect of arsenic on grain yield of T. Aman rice. Similar to the direct effect, the grain yield gradually decreased corresponding to the doses of arsenic increased, the yield range being $6.58-31.50 \mathrm{~g} \mathrm{pot}^{-1}$ (Table 3). The adverse effect of arsenic was further deteriorated due to $\mathrm{P}$ application. For instance, the grain yields due to $30 \mathrm{ppm}$ As along with $0,20,40,60$ and $80 \mathrm{ppm} P$ were $30.01,13.25,6.68,6.40$, and $4.70 \mathrm{~g} \mathrm{pot}^{-1}$, respectively (Fig. 1). On the contrary, the straw yield was not affected by residual arsenic showing a narrow range of $17.5-20.0 \mathrm{~g} \mathrm{pot}^{-1}$.

Table 3. Effects of arsenic and phosphorus on the yield and yield components of $T$. Aman rice (cv. BRRI dhan33)

\begin{tabular}{|c|c|c|c|c|c|}
\hline $\begin{array}{l}\text { Treatment } \\
\text { (As or } \mathrm{P} \text { ) }\end{array}$ & $\begin{array}{c}\text { Effective tillers } \\
\text { pot }^{-1}\end{array}$ & $\begin{array}{c}\text { Filled grains } \\
\text { panicle }{ }^{-1}\end{array}$ & $\begin{array}{l}\text { 1000-grain } \\
\text { weight }(\mathrm{g})\end{array}$ & $\begin{array}{c}\text { Grain yield } \\
\left.(\mathrm{g} \mathrm{pot})^{-1}\right)\end{array}$ & $\begin{array}{c}\text { Straw yield } \\
\left(\mathrm{g} \mathrm{pot}^{-1}\right)\end{array}$ \\
\hline \multicolumn{6}{|l|}{ As (ppm) } \\
\hline 0 & $21.67^{\mathrm{a}}$ & $55.93^{\mathrm{a}}$ & $23.63^{a}$ & $31.50^{a}$ & $38.76^{a}$ \\
\hline 15 & $12.40^{b}$ & $30.42^{b}$ & $23.02^{a}$ & $8.56^{b}$ & $10.57^{b}$ \\
\hline 30 & $10.20^{b}$ & $21.75^{b}$ & $21.93^{b}$ & $6.58^{b}$ & $7.89^{b}$ \\
\hline S.E. ( \pm$)$ & 1.97 & 4.74 & 0.36 & 1.74 & 2.13 \\
\hline \multicolumn{6}{|l|}{$\mathrm{P}(\mathrm{ppm})$} \\
\hline 0 & 15.33 & 38.10 & 22.94 & 14.20 & 17.47 \\
\hline 20 & 14.44 & 36.10 & 23.08 & 15.81 & 19.50 \\
\hline 40 & 13.67 & 37.46 & 22.64 & 15.45 & 18.67 \\
\hline 60 & 15.56 & 34.39 & 23.11 & 16.26 & 20.00 \\
\hline 80 & 14.78 & 34.20 & 22.54 & 16.01 & 19.73 \\
\hline S.E. $( \pm)$ & NS & NS & NS & NS & NS \\
\hline
\end{tabular}

S.E. $=$ Standard error of means $\quad$ NS = Not significant

In a column, the figures having same letter do not differ significantly at $5 \%$ level by DMRT.

\section{Effect on yield parameters}

Application of arsenic to the previous crop (Boro rice) had significantly affected the number of effective tillers pot ${ }^{-1}$ (Table 3 ) and thus, the As control performed the highest result (21.67) and the $30 \mathrm{ppm}$ As did the lowest (10.20). Similar residual effect of arsenic was noticed in case of grains panicle ${ }^{-1}$ indicating that As control treatment demonstrated the best result (55.9 grains panicle ${ }^{-1}$ ) and the $30 \mathrm{ppm}$ As had the worst result (21.8 grains panicle $\left.{ }^{-1}\right)$. The grains panicle ${ }^{-1}$ due to 15 and $30 \mathrm{ppm}$ As treatments was identical. Concerning 1000-grain weight, the As control performed the best result $(23.63 \mathrm{~g})$ which was statistically similar to that obtained with $15 \mathrm{ppm}$ As, but differed significantly with $30 \mathrm{ppm}$ As result (21.93 g). The interaction effect of $A s$ and $P$ on the yield parameters was not significant.

\section{Effect on As, $\mathrm{N}$ and $\mathrm{P}$ concentrations}

Arsenic had significant residual effect on the As, $\mathrm{N}$ and $\mathrm{P}$ concentrations of rice. Arsenic concentrations of both grain and straw showed an increasing trend with arsenic doses, the range being $0.185-0.210 \mathrm{ppm}$ grain-As and $2.88-3.55 \mathrm{ppm}$ straw-As (Table 4). The $\mathrm{P}$ effect was also significant on the As content, the grain-As ranged from $0.095-0.290 \mathrm{ppm}$ and the straw-As from $1.65-4.43 \mathrm{ppm}$. The As X P interaction was also significant with the highest grain-As concentration (0.315 ppm) recorded with $\mathrm{P}_{80} \mathrm{As}_{30}$ (Fig. 1) and $4.81 \mathrm{ppm}$ straw-As with $\mathrm{P}_{80} \mathrm{As}_{15}$. Significant effect of residual As was also observed in $\mathrm{P}$ concentration of rice grain which varied between 0.30 and $0.38 \%$. The straw-P content varied within a 
narrow range, $0.15-0.17 \%$. The As-P interaction on $\mathrm{P}$ concentration in both grain and straw was significant. The maximum grain- $P$ concentration $(0.48 \%)$ was found with $\mathrm{P}_{60} \mathrm{As}_{15}$ treatment while the highest straw-P concentration (0.23\%) was recorded with $\mathrm{P}_{80} \mathrm{As}_{30}$ treatment.

Table 4. Effects of arsenic and phosphorus on the As, $N$ and $P$ concentrations in $T$. Aman rice (cv. BRRI dhan33)

\begin{tabular}{|c|c|c|c|c|c|c|}
\hline \multirow{2}{*}{$\begin{array}{l}\text { Treatment } \\
\text { (As or } P \text { ) }\end{array}$} & \multicolumn{2}{|c|}{ N conc. $(\%)$} & \multicolumn{2}{|c|}{$\mathrm{P}$ conc. $(\%)$} & \multicolumn{2}{|c|}{ As conc. (ppm) } \\
\hline & Grain & Straw & Grain & Straw & Grain & Straw \\
\hline \multicolumn{7}{|l|}{ As (ppm) } \\
\hline 0 & $1.14^{\mathrm{D}}$ & $0.71^{b}$ & $0.30^{b}$ & $0.15^{b}$ & $0.185^{\mathrm{C}}$ & $2.88^{\mathrm{C}}$ \\
\hline 15 & $1.18^{\mathrm{a}}$ & $0.75^{\mathrm{a}}$ & $0.31^{b}$ & $0.15^{b}$ & $0.200^{b}$ & $3.21^{b}$ \\
\hline 30 & $1.12^{b}$ & $0.73^{b}$ & $0.38^{a}$ & $0.17^{a}$ & $0.210^{\mathrm{a}}$ & $3.55^{a}$ \\
\hline S.E. $( \pm)$ & 0.03 & 0.01 & 0.04 & 0.01 & 0.006 & 0.04 \\
\hline \multicolumn{7}{|l|}{$\mathrm{P}(\mathrm{ppm})$} \\
\hline 0 & $1.10^{\mathrm{C}}$ & $0.67^{c}$ & 0.33 & $0.17 a b$ & $0.095^{\mathrm{e}}$ & $1.65^{\mathrm{d}}$ \\
\hline 20 & $1.13^{b}$ & $0.80^{b}$ & 0.34 & $0.13 c$ & $0.120^{\mathrm{d}}$ & $2.39^{\mathrm{C}}$ \\
\hline 40 & $1.14^{\mathrm{b}}$ & $0.85^{a}$ & 0.38 & $0.16 b$ & $0.265^{b}$ & $3.65^{b}$ \\
\hline 60 & $1.17^{\mathrm{a}}$ & $0.69^{c}$ & 0.31 & $0.16 b$ & $0.225^{\mathrm{C}}$ & $4.43^{a}$ \\
\hline 80 & $1.19^{\mathrm{a}}$ & $0.64^{d}$ & 0.28 & $0.18 a$ & $0.290^{\mathrm{a}}$ & $4.17^{\mathrm{a}}$ \\
\hline S.E. $( \pm)$ & 0.02 & 0.01 & NS & 0.01 & 0.004 & 0.03 \\
\hline
\end{tabular}

S.E. $=$ Standard error of means $\quad$ NS $=$ Not significant

In a column, the figures having same letter do not differ significantly at $5 \%$ level by DMRT.

The study reveals that the grain yield was drastically reduced due to arsenic addition and it was associated with reduction in tillers and grain set, as evidenced in both Boro and T. Aman rice. The toxic effect of arsenic was further deteriorated for $P$ supplement to soil (Fig. 1). This result can be interpreted that added phosphate displaced sorbed arsenate from exchange sites, and therefore, increased the concentration of arsenic in the rhizosphere soil solution for subsequent uptake by rice roots (Peryea and Kammereck, 1997; Qafoku et al., 1999; Abedin, 2002).

The grain arsenic concentration for all arsenic treatments was below $1 \mu \mathrm{g} \mathrm{g}^{-1}$, the maximum permissible limit (NFA, 1993) according to Australian Food Standard, however this concentration can not be ignored as because, the majority people of Bangladeshi eat rice at least twice a day. Again, the straw arsenic concentration in most cases far exceeded the $1 \mu \mathrm{g}$ $\mathrm{g}^{-1}$ limit which also deserves attention since rice straw is a common feed for cattle.

Many workers at home and abroad have reported low concentration of arsenic in rice grain (Abedin, 2002; Panaullah et al., 2003; Williams et al., 2006) and elevated concentration in rice straw (Marin et al., 1992; Marin et al., 1993; Xie and Huang, 1998) for arsenic contamination of nutrient media or soil. Jahiruddin et al. (2003) reported a $40 \%$ grain yield reduction for $10 \mathrm{mg} \mathrm{kg}^{-1}$ arsenic addition to BAU farm soil. Islam et al. (2004) observed an adverse effect of arsenic contamination on the $\mathrm{N}$ and $\mathrm{P}$ concentrations of rice grain. Hossain et al. (2008) observed the addition of $P$ resulted in higher As concentrations in both grain and straw and lower grain yields.

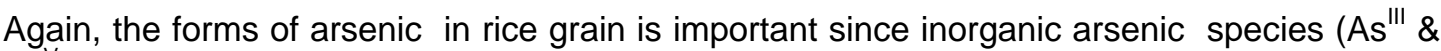
$A s^{v}$ ) are believed to be more toxic than organic arsenic (MMA \& DMA), however arsenic speciation has not been done in the present study. Williams et al. (2005) observed that $64 \%$ of European, $80 \%$ of Bangladeshi and $81 \%$ of Indian rice arsenic were inorganic, with As(III) predominating. 


\section{Conclusions}

The addition of arsenic markedly increased the arsenic concentration of grain and straw, with a concomitant reduction in grain and straw yields of rice. The situation was further deteriorated for $\mathrm{P}$ application to soil, probably due to displacement of arsenic from adsorption sites in the bulk soil, with an increased concentration of arsenic in the rhizosphere soil solution for subsequent uptake by rice roots. Rice straw can be a potential exposure of arsenic to cattle. Future research needs to be carried out on arsenic speciation and also to determine the maximum acceptable limit of arsenic in irrigation water, rice grain and straw under Bangladesh situation.

\section{Acknowledgement}

The authors are grateful to IRRI-PETRRA, Bangladesh for providing financial support to carry out this work.

\section{References}

Abedin, M.J. 2002. Arsenic Uptake, Metabolism and Toxicity in Paddy Rice (Oryza sativa L). Ph.D. Dissertation. University of Aberdeen, Scotland, UK.

Beever, R.E. and Burns, D.W. 1980. Phosphorous uptake, storage and utilization by fungi. Adv. Bot. Res. 8, 127219.

Hossain, M.B., Jahiruddin, M., Panaullah, G.M., Loeppert, R.H., Islam, M.R. and Duxbury, J.M. 2008. Spatial variability of arsenic concentration in soils and plants, and its relationship with iron, manganese and phosphorus. Environ. Pollut. 156: 739-744.

Hossain, M.B., Jahiruddin, M., Loeppert, R.H., Panaullah, G.M., Islam, M.R. and Duxbury, J.M. 2008. The effects of iron plaque and phosphorus on arsenic accumulation and yield in rice. Plant Soil. doi :10.1016/j.envpol.2008.06.05.

Huq, S.M.I., Joardar, J.C., Parveen, S., Correll, R. and Naidu, R. 2006. Arsenic contamination in food - chain: Transfer of arsenic into food materials through groundwater irrigation. J. Health Popul. Nutr. 24(3), 305316.

Islam, M.R., Jahiruddin, M. and Islam, S. 2004. Assessment of arsenic in the water-soil-plant systems in Gangetic floodplains of Bangladesh. Asian J. Plant Sci. 3(4), 480-483.

Islam, M.R., Jahiruddin, M., Rahman, G.K.M.M., Miah, M.A.M., Farid, A.T.M., Panaullah, G.M., Loeppert, R.H., Duxbury, J.M. and Meisner, C.A. 2005. Arsenic in paddy soils in Bangladesh: levels, distribution and contribution of irrigation and sediments. In "Behaviour of Arsenic in Aquifers, Soil and Plants: Implications for Management". Dhaka.

Jahiruddin, M., Harada, H., Hatanaka, T. and Islam. M.R. 2000. Status of trace elements in agricultural soils of Bangladesh and relationship with soil properties. Soil Sci. Plant Nutr. 46(4), 963-968.

Jahiruddin, M., Islam, M.R. and Ghani, M.A. 2003. Yield loss of rice due to use of arsenic contaminated soil and irrigation water. In " $7^{\text {th }}$ International Conference on the Biogeochemistry of Trace Elements", Ed. Gobran, G.R. and Lepp N., Vol. 2: pp. 78-79.

Marin, A.R., Masscheleyn, P.H and Patrick, W.H. Jr.1992. The influence of chemical form and concentration of arsenic on rice growth and tissue arsenic concentration. Plant Soil 139, 175-183.

Marin, A.R., Pezeshki, S.R., Masscheleyn, P.H. and Choi, H.S. 1993. Effect of dimethylarsenic acid (DMAA) on growth, tissue arsenic, and photosynthesis of rice plants. J. Plant Nutr. 16, 865-880.

NFA (National Food Authority). 1993. Australian Food Standard Code: 1993. Australian Govt. Pub. Service, Canberra.

Panaullah, G.M., Ahmed, Z.U., Rahman, G.K.M.M., Jahiruddin, M., Miah, M.A.M., Farid, A.T.M., Biswas, B.K., Lauren, J.G., Loeppert, R.H., Duxburry, J.M. and Meisner, C.A. 2003. The arsenic hazard in the irrigation water-soil-plant system in Bangladesh: A preliminary assessment. In " $7^{\text {th }}$ International Conference on the Biogeochemistry of Trace Elements", Ed. Gobran, G.R and Lepp. N., Vol. 2, pp. 104-105. 
Ravenscroft, P., Burgess, W.L., Ahmed, K.M., Burren, M., Perrin, J. 2005. Arsenic in groundwater of the Bengal Basin, Bangladesh: Distribution, field relations, and hydrogeological setting. Hydrogeo. J. 13, 727-751.

Roberts, L.C., Hug, S.J., Dittmar, J., Voegelin, A., Saha, G.C., Ali, M. A., Badruzzaman, A.B.M., Kretzschmar, R. 2007. Spatial distribution and temporal variability of arsenic in irrigated rice fields in Bangladesh. I. Irrigation Water. Environ. Sci. Technol. 41, 5960-5966.

Peryea, F.J. and Kammereck, R. 1997. Phosphate- enhanced movement of arsenic out of lead arsenatecontaminated topsoil and through uncontaminated subsoil. Water Air Soil Pollut. 93, 243-254.

Qafoku, N.P., Kukier, U., Sumner, M.E., Miller, W.P. and Radcliffe, D.E. 1999. Arsenate displacement from fly ash amended soils. Water Air Soil Pollut. 114, 185-198.

Williams, P.N., Price, A.H., Raab, A., Hossain, S.A., Feldmann, J. and Meharg, A.A. 2005. Variation in arsenic speciation and concentration in paddy rice related to dietary exposure. Environ. Sci. Technol. 39, 55315540.

Williams, P.N., Islam, M.R., Admako, E.E., Zhu, Y.G., Price, Feldmann, J. and Meharg, A.A. 2006. Increase in rice grain arsenic for regions of Bangladesh irrigating paddies with elevated arsenic in groundwaters. Environ. Sci. Technol. 40, 4903- 4908.

Xie, Z. M. and Huang, C. Y. 1998. Control of arsenic toxicity in rice plants grown on an arsenic-polluted paddy soil. Commun. Soil Sci. Plant Anal. 29: 2471-2477. 